\title{
AKUMULASI BAHAN KERING BEBERAPA VARIETAS JAGUNG HIBRIDA (Zea mays L.) YANG DITUMPANGSARIKAN DENGAN UBIKAYU (Manihot esculenta Crantz)
}

\author{
Ragil Alsabah, Sunyoto, Kuswanta F. Hidayat \& M. Kamal \\ Jurusan Agroteknologi, Fakultas Pertanian Universitas Lampung \\ Jl. Prof. Soemantri Brodjonegoro, No. 1, Bandar Lampung 35145 \\ E-mail: ragilalsabah@ rocketmail.com
}

\begin{abstract}
ABSTRAK
Sistem tumpangsari jagung dengan ubikayu merupakan cara untuk mengoptimalisasi penggunaan lahan.Bahan kering tanaman merupakan ukuran yang paling sering digunakan untuk menggambarkan dan mempelajari pertumbuhan tanaman. Penelitian ini bertujuan untuk: 1). mengetahui akumulasi bahan kering tanaman jagung yang ditanam secara monokultur dan tumpangsari dengan ubikayu, 2). mengetahui akumulasi bahan kering beberapa varietas jagung hibrida dalam sistem tumpangsari dengan ubikayu. Penelitian ini dilaksanakan di Kebun Percobaan BPTP, Kecamatan Natar, Kabupaten Lampung Selatan dan Laboratorium Ilmu Tanaaman, Fakultas Pertanian, Universitas Lampung pada bulan November 2012 sampai Maret 2013. Perlakuan disusun secara faktorial dengan petak terbagi dalam Rancangan Acak Kelompok (RAK) dengan 3 ulangan.Petak utama adalah pola pertanaman tumpangsari dan monokultur, sedangkan anak petak adalah varietas tanaman jagung yang terdiri atas P27, DK77, DK85, DK95 dan NK22. Petak percobaan yang digunakan pada penelitian ini berukuran 4 x 3,2 m. Data dianalisis dengan ANOVA dan perbedaan nilai tengah perlakuan ditentukan dengan uji beda nyata jujur pada taraf nyata $5 \%$. Hasil penelitian menunjukkan bahwa akumulasi bahan kering tanaman jagung yang ditanam secara monokultur dan tumpangsari menunjukkan perbedaan secara nyata; bahan kering pada tanaman jagung secara monokultur memiliki nilai yang lebih besar daripada tanaman yang dibudidayakan secara tumpangsari. Sebagian bahan kering diakumulasikan pada biji diikuti batang, daun, akar, tongkol, kelobot dan malai. Akumulasi bahan kering pada beberapa varietas jagung yang ditanam secara tumpangsari menunjukkan perbedaan tidak nyata. Namun demikianvarietas NK22 menunjukkan akumulasi bahan kering yang paling besar dibandingkan dengan varietas DK85, DK77, DK95 dan P27.
\end{abstract}

Kata kunci : bahan kering, jagung, monokultur, tumpangsari.

\section{PENDAHULUAN}

Jagung (Zea mays L.) merupakan tanaman pangan nasional kedua setelah padi dan perannya semakin meningkat sejalan bertambahnya jumlah penduduk, usaha peternakan, dan berkembangnya industri olahan berbahan baku jagung.Di beberapa daerah di Indonesia, jagung dijadikan sebagai bahan pangan utama juga sebagai sumber bahan pakan ternak.Peningkatan kebutuhan jagung dalam beberapa tahun terakhir ini tidak sejalan dengan peningkatan produksi dalam negeri. Kebutuhan jagung Indonesia diprediksi akan terus meningkat seiring berkembangnya industri peternakan dan pangan (Dewanto et al., 2003) sebaliknya luas area pertanaman jagung pada tahun 2008-2012 terus mengalami penurunan (Badan Pusat Statistik, 2013). Untuk meningkatkan produksi jagung salah satunya dengan penggunaan varietas hibrida, jagung hibrida memiliki beberapa kelebihan yaitu toleran terhadap hama penyakit, tanggap terhadap pemupukan, tongkol lebih seragam, jumlah biji lebih banyak dan lebih berat (Jugenheimer, 1985 dalam Hipi et al., 2006). Selain jagung komoditas ubikayu juga prospektif untuk dikembangkan di Indonesia.Agroindustri berbasis ubikayu akhir-akhir ini cukup berkembang.Badan Pusat Statistik (2011), ekspor ubikayu atau singkong berupa gaplek mencapai 40,9 juta ton, tapioka 83,15 juta ton dan bentuk lain mencapai 1,2 juta ton.

Banyak usaha untuk meningkatkan produksi pertanian diantaranya adalah intensifikasi dan ekstensifikasi.Usaha ekstensifikasi tampaknya dibatasi oleh areal pertanian subur yang cenderung semakin terbatas.Hal ini dijelaskan oleh Nasution (2004) bahwa alih fungsi lahan pertanian ke sektor non pertanian mencapai 47 ribu hektar per tahun. Oleh karena itu dalam rangka meningkatkan produksi jagung antara lain dapat ditempuh dengan beberapa cara, diantaranya penerapan pola pertanaman tumpangsari dengan menyisipkan 
tanaman jagung pada pertanaman ubikayu. Menurut Buhaira (2007) tumpangsari adalah salah satu sistem tanam dengan dua atau lebih jenis tanaman yang berbeda ditanam secara bersamaan dengan penanaman berselang-seling dan jarak tanam teratur pada sebidang tanah yang sama. Keuntungan pertanaman tumpangsari dapat meningkatkan efisiensi penggunaan unsur hara, air dan matahari. Hal ini diperkuat oleh (Tohari et al., 2011) yangmenyatakan bahwa pola pertanaman tumpangsari jagung dengan kacang hijau dapat meningkatkan efisiensi penggunaan air $60,8 \%$.

Salah satu kendala pada pola pertanaman tumpangsari khususnya jagung dengan ubikayu adalah belum adanya referensi mengenai produktivitas. Produktivitas tanaman dapat dilihat dengan mengetahuiakumulasi bahan kering. Akumulasi bahan kering adalah penyebaran hasil dari kegiatan fotosintesis pada bagian-bagian tanaman seperti akar, batang, daun dan bagian generatif.Akumulasi bahan kering mencerminkan kemampuan tanaman dalam menyerap cahaya matahari melalui proses fotosintesis, serta interaksinya dengan faktor-faktor lingkungan lainnya (Sitompul dan Guritno, 1995).

Bahan kering tanaman juga merupakan ukuran yang paling sering digunakan untuk menggambarkan dan mempelajari pertumbuhan tanaman. Hal ini didasarkan karena bahan kering tanaman yang relatif lebih mudah diukur dan merupakan integrasi dari hampir semua proses metabolisme pada tanaman. Oleh karena itu parameter ini merupakan indikator pertumbuhan yang paling representatif dalam mendapatkan penampilan keseluruhan tanaman atau organ tertentu pada setiap periode pertumbuhan.

Akumulasi bahan kering pada tanaman jagung ditentukan oleh tinggi rendahnya intensitas cahaya matahari yang diterima permukaan daun jagung.Intensitas cahaya yang rendah akan mengurangi fotosintesis daun, bahan kering, jumlah biji, jumlah akar dan besar batang jagung. Hal ini didasarkan pada sifat tanaman jagung yang mempunyai laju fotosintesis tinggi dan tidak jenuh cahaya (Bunyamin dan Aqil, 2009).

Tujuan dari penelitian ini adalah untuk mengetahui akumulasi bahan kering tanaman jagung yang ditanam secara monokultur dan tumpangsari dengan ubikayu serta akumulasi bahan kering beberapa varietas jagung hibrida dalam sistem tumpangsari dengan ubikayu.

\section{BAHAN DAN METODE}

Penelitian dilaksanakan di Kebun Percobaan Balai Pengkajian Teknologi Pertanian (BPTP) Desa Negara Ratu, Kecamatan Natar, Kabupaten Lampung Selatan dan Laboratorium Ilmu Tanaman, Fakultas Pertanian, Universitas Lampung pada bulan November 2012 sampai Maret 2013. Bahan yang digunakan adalah stek ubikayu klon Kasesart dan benih jagung hibrida yang terdiri dari 5 varietas yaitu; P27, DK77, DK85, DK95 dan NK22. Alat yang digunakan dalam penelitian ini adalah oven tipe Herseus T5050, timbangan Ohaus sensitivitas $0,1 \mathrm{~g}$, tali rafia, bambu, meteran, gembor, cangkul, kertas koran, kertas label, pisau dan alat tulis.

Perlakuan disusun secara faktorial dengan petak terbagi dalam Rancangan Acak Kelompok (RAK) dengan 3 ulangan.Petak utama adalah pola pertanaman tumpangsari dan monokultur sedangkan anak petak adalah varietas tanaman jagung yang terdiri atas lima varietas P27, DK77, DK85, DK95 dan NK22. Dengan demikian jumlah petak percobaan adalah 30 petak percobaan dengan ukuran petak 3,2 $\mathrm{m}$ x $4 \mathrm{~m}$. Jarak tanam ubikayu $80 \mathrm{~cm} \times 60 \mathrm{~cm}$ dan jagung $80 \mathrm{~cm} \times 20$ $\mathrm{cm}$.

Parameter yang diamati adalah; Bobot kering batang, Bobot kering daun, Bobot kering akar, Bobot kering malai masing-masing pada umur 4-13 mst dengan interval pengamatan 2 minggu. Bobot kering biji, Bobot kering tongkol, Bobot kering kelobot, dan indeks panen (IP)masing-masing pada umur 8, 9, 10 dan 13 mst.

Data hasil pengamatan dianalisis dengan ANOVA. Perbedaan nilai tengah perlakuan ditentukan dengan uji beda nyata jujur pada taraf nyata $5 \%$.

\section{HASIL DAN PEMBAHASAN}

Pengaruh pola pertanaman menyebabkan perbedaan nyata pada bobot kering daun umur 4, 6 dan 13 mst (Tabel 2 dan 3); akumulasi bahan kering daun pada pertanaman tumpangsari lebih besar dibandingkan dengan monokultur.Hasil tersebut karena pada pola pertanaman tumpangsari umur 4 dan 6 mst daun tanaman jagung bagian bawah mulai ternaungi oleh tajuk tanaman ubikayu dan pada umur 13 mst tinggi tanaman keduanya sama menyebabkan terjadinya persaingan dalam memperebutkan cahaya matahari. Hal ini sesuai dengan penelitianYunus (2007), bahwa pada pola pertanaman tumpangsari jagung dengan kelapa menunjukkan perbedaan jumlah dan luas daun yang nyata dibandingkan dengan pola pertanaman monokultur. Menurut Sitompul dan Guritno (1995) ukuran daun akan berkurang akibat adanya perbedaan proporsi cahaya matahari yang diterima oleh permukaan daun.

Bobot kering daunpada pola pertanaman tumpangsari umur 4 dan 6 mstmenunjukkan akumulasi bahan kering terbesar diikuti batang, akar dan malai. Sedangkan pada umur 8 dan 10 mstakumulasi bahan 
kering terbesar terdapat pada batang dikuti daun, biji, tongkol,akar dan malai. Sementara itu pada umur 13 mst bobot biji menunjukkan akumulasi bahan kering yang terbesar diikuti batang, daun, akar, tongkol, kelobot dan malai.
Pengaruh pola pertanaman menyebabkan perbedaan nyata pada bobot kering batang umur 10 dan 13 mst (Tabel 1), sedangkan pengaruh varietas menyebabkan perbedaan nyata pada bobot kering batang umur 4, 6 dan 13 mst. Hasil ini disebabkan oleh

Tabel 1. Signifikasi pengaruh pola pertanaman, varietas jagung dan interaksinya terhadap variabel pertumbuhan dan hasil tanaman jagung.

\begin{tabular}{|c|c|c|c|}
\hline Pengamatan & Pola Pertanaman & Varietas & Interaksi \\
\hline Bobot kering daun (4 mst) & $*$ & $*$ & tn \\
\hline Bobot kering daun (6 mst) & $*$ & $*$ & tn \\
\hline Bobot kering daun ( $8 \mathrm{mst}$ ) & tn & tn & $*$ \\
\hline Bobot kering daun (10 mst) & tn & tn & $*$ \\
\hline Bobot kering batang (4 mst) & tn & $*$ & tn \\
\hline Bobot kering batang (6 mst) & tn & tn & tn \\
\hline Bobot kering batang (8 mst) & $\operatorname{tn}$ & $\operatorname{tn}$ & $*$ \\
\hline Bobot kering batang (10 mst) & $*$ & $*$ & tn \\
\hline Bobot kering akar (4 mst) & $*$ & $*$ & tn \\
\hline Bobot kering akar (6 mst) & $*$ & $*$ & tn \\
\hline Bobot kering akar (8 mst) & th & $*$ & tn \\
\hline Bobot kering akar (10 mst) & tn & $*$ & tn \\
\hline Bobot kering malai (8 mst) & $*$ & tn & tn \\
\hline Bobot kering malai (9 mst) & tn & tn & $\operatorname{tn}$ \\
\hline Bobot kering malai (10 mst) & tn & tn & tn \\
\hline Bobot kering malai (11 mst) & tn & tn & $\operatorname{tn}$ \\
\hline Bobot kering kelobot (8 mst) & $\operatorname{tn}$ & $\operatorname{tn}$ & $\operatorname{tn}$ \\
\hline Bobot kering kelobot (9 mst) & $*$ & $\operatorname{tn}$ & $\operatorname{tn}$ \\
\hline Bobot kering kelobot (10 mst) & $*$ & tn & $\operatorname{tn}$ \\
\hline Bobot kering kelobot (11 mst) & tn & $\operatorname{tn}$ & $\operatorname{tn}$ \\
\hline Bobot kering tongkol (8 mst) & tn & tn & tn \\
\hline Bobot kering tongkol (9 mst) & $\operatorname{tn}$ & $*$ & $\operatorname{tn}$ \\
\hline Bobot kering tongkol (10 mst) & $\operatorname{tn}$ & $*$ & $\operatorname{tn}$ \\
\hline Bobot kering tongkol (11 mst) & $*$ & $*$ & $\operatorname{tn}$ \\
\hline Bobot kering biji (9 mst) & $\operatorname{tn}$ & $\operatorname{tn}$ & $\operatorname{tn}$ \\
\hline Bobot kering biji (10 mst) & tn & $*$ & tn \\
\hline Bobot kering biji (11 mst) & $\operatorname{tn}$ & $*$ & $\operatorname{tn}$ \\
\hline \multicolumn{4}{|l|}{ Panen } \\
\hline Bobot kering daun (13 mst) & tn & $\operatorname{tn}$ & $*$ \\
\hline Bobot kering batang (13 mst) & $*$ & $*$ & tn \\
\hline Bobot kering akar (13 mst) & $*$ & $*$ & tn \\
\hline Bobot kering malai (13 mst) & $*$ & $\operatorname{tn}$ & $\operatorname{tn}$ \\
\hline Bobot kering kelobot (13 mst) & tn & $\operatorname{tn}$ & tn \\
\hline
\end{tabular}

Keterangan: $*=$ Berbeda nyata pada uji $\mathrm{BNJ}$ taraf $5 \%, \mathrm{tn}=$ Tidak berbeda nyata pada uji $\mathrm{BNJ}$ taraf $5 \%$. 
Tabel 2. Pengaruh pola pertanaman dan varietas jagung terhadap Bobot kering daun, batang dan akar pada umur 4 dan 6 mst dalam gram.

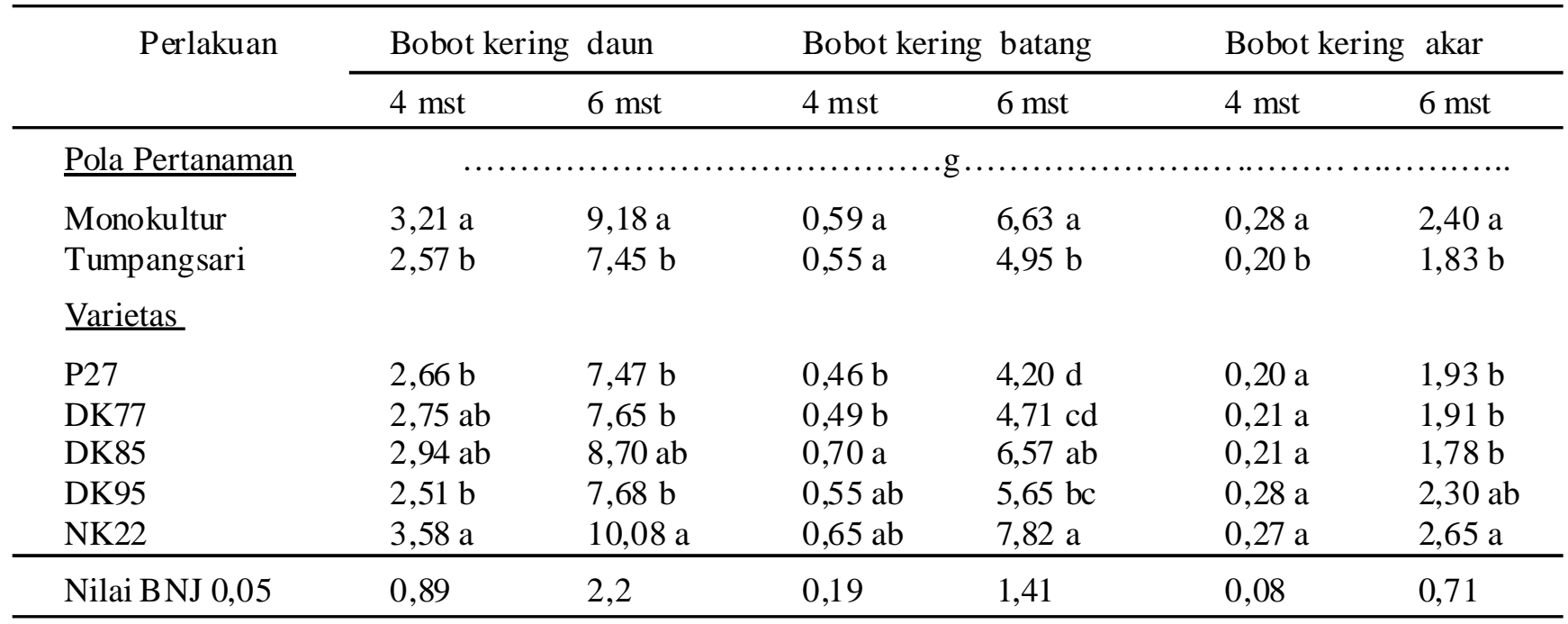

Keterangan: Angka- angka yang diikuti huruf yang sama pada kolom yang sama tidak berbeda nyata menurut uji BNJ pada taraf $5 \%$.

Tabel 3. Pengaruh pola pertanaman dan varietas jagung terhadap Bobot kering daun, batang, akar, malai, kelobot, tongkol, biji dan Indeks panen pada saat panen (13 mst) dalam gram.

\begin{tabular}{|c|c|c|c|c|c|c|c|c|}
\hline Perlakuan & $\begin{array}{c}\text { Bobot } \\
\text { kering } \\
\text { daun }\end{array}$ & $\begin{array}{l}\text { Bobot } \\
\text { kering } \\
\text { batang }\end{array}$ & $\begin{array}{c}\text { Bobot } \\
\text { kering } \\
\text { akar }\end{array}$ & $\begin{array}{l}\text { Bobot } \\
\text { kering } \\
\text { malai }\end{array}$ & $\begin{array}{l}\text { Bobot } \\
\text { kering } \\
\text { kelobot }\end{array}$ & $\begin{array}{l}\text { Bobot } \\
\text { kering } \\
\text { tongkol }\end{array}$ & $\begin{array}{l}\text { Bobot } \\
\text { kering } \\
\text { biji }\end{array}$ & $\begin{array}{l}\text { Indeks } \\
\text { panen }\end{array}$ \\
\hline$\underline{\text { Pola Pertanaman }}$ & & 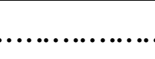 & ......... & $\ldots . \mathrm{g}$. & $\ldots \ldots$ & ....... & ..... & $\ldots \% \ldots$ \\
\hline Monokultur & $31,09 \mathrm{a}$ & $61,50 \mathrm{a}$ & $11,81 \mathrm{a}$ & $2,01 \mathrm{a}$ & $21,75 \mathrm{a}$ & $25,78 \mathrm{a}$ & $97,04 \mathrm{a}$ & $38,54 \mathrm{a}$ \\
\hline Tumpangsari & $30,36 \mathrm{a}$ & $54,94 \mathrm{~b}$ & $10,49 b$ & $1,55 \mathrm{~b}$ & $20,15 \mathrm{a}$ & $22,81 \mathrm{a}$ & $89,67 \mathrm{~b}$ & $38,97 \mathrm{a}$ \\
\hline \multicolumn{9}{|l|}{$\underline{\text { Varietas }}$} \\
\hline $\mathrm{P} 27$ & $6.93 \mathrm{a}$ & $51,08 \mathrm{~b}$ & $9,78 \mathrm{~b}$ & $1,67 \mathrm{a}$ & $18,91 \mathrm{a}$ & $18,96 \mathrm{~b}$ & $86,26 \mathrm{~b}$ & $40,32 \mathrm{a}$ \\
\hline DK77 & $33.01 \mathrm{a}$ & $58,73 \mathrm{a}$ & $10,87 \mathrm{~b}$ & $1,66 \mathrm{a}$ & 20,11 a & $22,87 \mathrm{~b}$ & $91,97 \mathrm{~b}$ & $38,41 \mathrm{a}$ \\
\hline DK85 & $34.33 \mathrm{a}$ & $59,06 \mathrm{a}$ & $10,90 \mathrm{~b}$ & $1,69 \mathrm{a}$ & $20,53 \mathrm{a}$ & $25,13 \mathrm{ab}$ & $92,55 \mathrm{~b}$ & $37,78 \mathrm{a}$ \\
\hline DK95 & $29.10 \mathrm{a}$ & $58,06 \mathrm{ab}$ & $11,01 \mathrm{~b}$ & $1,88 \mathrm{a}$ & $20,86 \mathrm{a}$ & $22,70 \mathrm{~b}$ & $91,13 \mathrm{~b}$ & $38,67 \mathrm{a}$ \\
\hline NK22 & $30.23 \mathrm{a}$ & $64,15 \mathrm{a}$ & $13,20 \mathrm{a}$ & $1,99 \mathrm{a}$ & $24,34 \mathrm{a}$ & $31,83 \mathrm{a}$ & $104,85 \mathrm{a}$ & $38,61 \mathrm{a}$ \\
\hline Nilai BNJ 0,05 & 4,20 & 0,94 & 3,08 & 0,46 & 5,67 & 3,35 & 4,81 & 2,91 \\
\hline
\end{tabular}

Keterangan: Angka- angka yang diikuti huruf yang sama pada kolom yang sama tidak berbeda nyata menurut uji BNJ pada taraf $5 \%$.

tanaman jagung pada umur ini sedang mengalami fase pengisian biji yang cepat sehingga persaingan antartanaman dalam memperebutkan cahaya mataharisedang terjadi. Menurut Sitompul dan Guritno (1995) kompetisi yang terjadi antartanaman pada sebuah populasi tanaman mula-mula menunjukkan persaingan yang rendah, seiring bertambahnya umur dan tajuk tanaman menyebabkan kompetisi antartanaman semakin tinggi. Pengaruh pola pertanaman menyebabkan perbedaan nyata pada bobot kering akar umur 4. 6 dan 13 mst (Tabel 1). Hal ini disebabkan karena akumulasi bahan kering akar tanaman jagung sangat dipengaruhi oleh penaungan tanaman, penaungan menyebabkan akumulasi bahan kering yang ditranslokasikan ke organ tanaman yang letaknya berjauhan dengan organ fotosintesis akan mendapatkan proporsi yang lebih rendah. Menurut Suwarto et al. (2005) penurunan akumulasi bahan kering pada akar 
tanaman jagung dapat dianalogikan dengan penurunan hasil tanaman akibat gulma karena ada persaingan antar kedua spesies tanaman dalam mendapatkan faktor tumbuh.

Pengaruh pola pertanaman dan varietas menyebabkan perbedaan yang tidak nyata pada bobot kering malai umur 4-13 mst (Tabel 2 dan 3). Hasil tersebut disebabkan oleh daun yang berada dibagian atas mendapatkan intensitas cahaya matahari yang lebih banyak sehingga akumulasi bahan kering ditranslokasikan ke malai dalam jumlah yang sama dengan pertanaman monokultur. Hal ini diperkuat oleh Irianto (2007), yang menyatakan bahwa fotosintat dari daun akan ditranslokasikan ke organ terdekat yang sedang tumbuh dan berkembang. Sehingga fotosintat dari daun-daun bagian atas akan ditranslokasikan ke malai bunga jantan, batang bagian atas dan tongkol.

Pengaruh pola pertanaman dan varietas menyebabkan perbedaan yang nyata terhadap bobot kering kelobot, tongkol dan biji pada umur 9, 10 dan 11 mst (Tabel 1). Akan tetapi pengaruh pola pertanaman umur 13 mst menyebabkan perbedaan yang nyata terhadap bobot kering biji sedangkan pengaruh varietas menyebabkan perbedaan yang tidak nyata. Meskipun demikian secara umum varietas NK22 menunjukkan akumulasi bahan kering yang paling besar dibandingkan dengan varietas DK85, DK77, DK95 dan P27 (Tabel 3). Hasil ini disebabakan oleh tinggi tanaman ubikayu yang semakin bertambah sejak umur 9-13 mst mengakibatkan kompetisi antar tanaman yang semakin meningkat dalam memperebutkan sinar matahari. Akibat adanya kompetisi yang semakin meningkat menghasilkan perbedaan akumulasi bahan kering biji jagung.

Hasil tersebut diperkuat oleh penelitian Suwartoet al. (2005) yang menyatakan bahwa jagung mengalami kehilangan hasil biji apabila ditanam tumpangsari. Ratarata persentase kehilangan biji jagung adalah 9.7, 16.7, dan 16.9 persen;masing-masing untuk beberapa varietas.Menurut Kuruseng dan Wahab (2006) menyatakan bahwa perbedaan penampilan (fenotipe) dari berbagai varietas hibrida diakibatkan pengaruh genetik dan lingkungan.Lingkungan memberikan peranan dalam rangka penampakan karakter yang sebenarnya terkandung dalam gen tersebut.

Akumulasi bahan kering biji pada umur 10-13 mst mengalami pertambahan yang cepat. Akan tetapi akumulasi bahan kering pada organ vegetatif;akar, batang dan daun tidak banyak mengalami perubahan.Menurut Maintang dan Nurdin (2013) semakin tinggi bobot biji pipilan kering yang diperoleh berarti makin tinggi laju akumulasi bahan kering yang disalurkan ke biji.
Indeks panen kedua pola pertanaman dan kelima varietas menunjukkan perbebedaan yang tidak nyata. Hal ini menandakan bahwa perbandingan akumulasi bahan kering biji dan akumulasi bahan kering tanaman secara keseluruhan antara kedua pola pertanaman dan kelima varietas menunjukkan perbandingan yang sama. Menurut Kiswanto et al. (2012) akar dan tajuk tanaman jagung mempunyai fungsi sebagai penyalur fotosintat, sedangkan hasil yaitu berupa tongkol dan biji.Besar kecilnya tongkol dan biji yang dihasilkan tanaman akan sangat bergantung pada besar kecilnya akar dan tajuk tanaman.

Akumulasi bahan kering pada seluruh bagian tanaman jagung merupakan ukuran yang dapat menggambarkan produktivitas tanaman. Akumulasi bahan kering pada kedua pola pertanaman menunjukkan perbedaan yang nyata pada biji, akar, batang dan malai; akumulasi bahan kering yang ditanam secara tumpangsari menunjukkan nilai yang lebih kecil daripada monokultur, meskipun demikian perbedaan tersebut bukan merupakan alasan untuk tidak menerapakan pola tanam ini, karena penurunan produktivitas tanaman dapat digantikan oleh beberapa keuntungan antara lain jumlah gulma yang menurun, biaya pemeliharaan tanaman yang lebih efisien dan hasil dari ubikayu.

\section{KESIMPULAN}

Dari hasil penelitian yang telah dilakukan diperoleh kesimpulan bahwa akumulasi bahan kering tanaman jagung yang ditanam secara monokultur dan tumpangsari menunjukkan perbedaan secara nyata; bahan kering pada tanaman jagung secara monokultur memiliki nilai yang lebih besar daripada tanaman yang dibudidayakan secara tumpangsari. Sebagian bahan kering diakumulasikan pada biji diikuti batang, daun, akar, tongkol, kelobot dan malai. Akumulasi bahan kering pada beberapa varietas jagung yang ditanam secara tumpangsari tidak berbeda nyata. Namun demikian secara umum varietas NK22 menunjukkan akumulasi bahan kering yang paling besar dibandingkan dengan varietas DK85, DK77, DK95 dan P27.

\section{DAFTAR PUSTAKA}

Badan Pusat Statistik. 2011. Luas Areal Tanam Jagung Menurut Tahun. http://www.bps.go.id/ tnmn pgn.php?kat=3. Diakses pada tanggal : 10 November 2013. 
Badan Pusat Statistik, 2013. Ekspor Ubikayu Indonesia. http://www.bps.go.id/tnmn pgn. php ?kat $=3$ \&id subyek $=53$ \& notab $=0$. Diakses pada tanggal : 3 Januari 2014.

Buhaira, 2007. Respons Kacang Tanah (Arachis hypogaea L.) Dan Jagung (Zea mays L.) Terhadap Beberapa Pengaturan Tanam Jagung Pada Sistem Tanam Tumpangsari. Jurnal Agronomi. 11 (1):41-45. ISSN 1410-1939.

Bunyamin, Z dan M. Aqil, 2009. Pengaruh Sistem Pertanaman Sisipan Terhadap Pertumbuhan Tanaman Jagung. Prosiding Seminar Nasional Serealia 2009. ISBN 978-979-8940-27-9. Hlm 54-60.

Dewanto. G. F., J.J.M.R. Londok dan R. A. V.Tuturong. 2013. Pengaruh Pemupukan Anorganik Dan Organik Terhadap Produksi Tanaman Jagung Sebagai Sumber Pakan. Jurnal Zootek. 32 (5): 1-8. ISSN 0852-2626.

Hipi, A., B. T. R. Erawati dan M. A. Takdir. 2006. Potensi Hasil Galur Harapan Jagung Hibrida Pada Agroekosistem Lahan Kering Di Lombok Timur. Balitsereal. Maros. Sulawesi Selatan. Hlm 19-27.

Irianto.2007. Respon Tanaman Jagung Manis (Zea mays saccharata Sturt) Terhadap Pemberian Kompos Sampah Kota. Jurnal Agronomi. 11 (2): 95-97. ISSN 1410-1939.

Kiswanto, D. Indradewa, dan E. S. P. Putra. 2012. Pertumbuhan dan Hasil Jagung (Zea mays L.), Kacang Tanah (Arachis hypogaea L.), dan Jahe
(Zingiber officinale var. officinale) Pada Sistem Agroforestri Jati di Zona Ledok Wonosari, Gunung Kidul. LPPM UGM. Yogyakarta. Hlm 101-145.

Kuruseng, M dan A. Wahab. 2006. Respon Berbagai Varietas Tanaman Jagung Terhadap Waktu Perompesan Daun di Bawah Tongkol. Jurnal Agrisistem. 2(2): 86-93.

Maintang dan M. Nurdin. 2013.Pengaruh Waktu Penyerbukan Terhadap Keberhasilan Pembuahan Jagung Pada Populasi SATP-2 (S2)C6. Jurnal Agribisnis Kepulauan. 2 (2): 94-108.

Nasution, M. 2004. Diversifikasi Titik Kritis Pembangunan Pertanian Indonesia. Pertanian Mandiri. Penebar Swadaya. Jakarta.HIm 39.

Sitompul, S.M. dan B. Guritno. 1995. Analisis Pertumbuhan Tanaman. Gadjah Mada University Press. Yogyakarta. Hlm 77.

Suwarto, S., Y. Handoko dan M.A. Chozin. 2005. Kompetisi Tanaman Jagung dan Ubikayu dalam Sistem Tumpang Sari. Jurnal Agronomi. 2(33): 1-7.

Tohari, E. D., I. dewa dan D. Shiddieq. 2011. Respon Tanaman Jagung Tumpangsari Kacang Hijau Terhadap Perlakuan Parit Pada Lahan Kering. Jurnal Agrotropika. 1(16): 38-44.

Yunus, M. 2007. Analisis Pertanaman Jagung Pada Sistem Tumpangsari Dengan Tanaman Kelapa. Jurnal Agrisistem. 3 (2): 106-114. ISSN 18584330. 